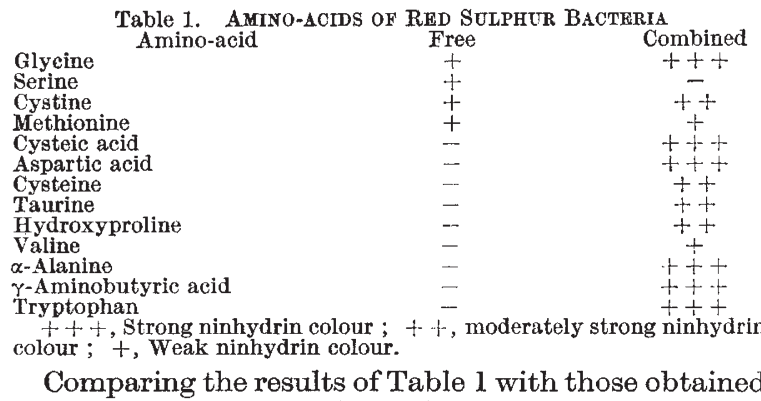

by Fowden ${ }^{1}$ in his work on the production of aminoacids by photosynthetic green algæ, it is seen that some of the important amino-acids which occur in algal proteins are also present in the proteins of red sulphur bacteria, but unlike the algæ, a few of the amino-acids occur in the free state in the bacterial proteins. Glycine occurs in appreciable quantities both as free and bound amino-acid in algal proteins, but in the case of red sulphur bacteria only traces of glycine are found in the alcoholic extract although an appreciable quantity of glycine occurs in the hydrolysate. $\gamma$-Aminobutyric acid occurs in appreciable quantities in the protein hydrolysate of red sulphur bacteria and in the free state in Chlorella vulgaris only. Glutamic acid and $\alpha$-alanine are found in large quantities in the free state in all the algæ, but in the case of red sulphur bacteria only $\alpha$-alanine is present in large quantities in the hydrolysate. Tryptophan occurs in large amounts in the hydrolysate of bacterial proteins but only in traces in algal proteins.

The important sulphur-containing amino-acids, namely, cystine, cysteine, methionine and cysteic acid figure prominently in the proteins of red sulphur bacteria ; but only cystine and methionine are found, in trace amounts, in algal proteins. Some of the essential amino-acids, namely, threonine, lysine, histidine, arginine, leucine, isoleucine are absent from the proteins of red sulphur bacteria. A smaller number of amino-acids are found in red sulphur bacteria than in algæ.

This work was done during the tenure of a fellowship at the Research Institutes of the University of Chicago, Fells Fund, Chicago, Illinois, U.S.A.

\section{H. MuKhERJEe}

University College of Science

and Technology,

Calcutta, India.

2 Fowden, L., Nature, 167, 1030 (1951).

2 Pearsall, W. H., and Fogg, C. F., Food Sci. Abs. (D.S.I.R.), 23, 1 (1951)

3 Eny, D. M., J. Bact., 42, 238 (1949)

Hendley, D. D., J. Bact., 70, 625 (1955)

'Larson, H., J. Baet., 64, 187 (1952)

Van Neil, C. B., Arch. Mikrobiol., 7, 323 (1936).

Piez, K. A., Tooper, K. B., et al., J. Biol. Chem, 194, 669 (1952).

\section{A New Nitrogen-Fixing Bacterium}

A Nitroghn-FIxing bacterium apparently different from all previously known organisms with this property was isolated from West Bengal soil by one of us (R.B.).

The bacterium appears after 20-24 hr. in nitrogen. deficient glucose or mannitol agar as big rods with rounded ends and homogeneous cytoplasm (measuring $3 \cdot 5-6 \cdot 0 \times 1 \cdot 0-1 \cdot 2 \mu$ ); older cells vary in length and contain a row of refractile granules. Long filaments and swollen 'involution' forms arise in various media with combined nitrogen. The cells are Gram-negative and do not form endospores. Motility is sometimes seen but is quite erratic.
Cultures on nitrogen-deficient agar media show a characteristic uneven growth, at first thin and semitransparent, later with isolated areas of heavy, raised growth that becomes coarsely wrinkled and changes from pale yellow to dark red-brown. The consistency is exceedingly tough and rubber-like, with age becoming more soft and smeary. Growth in sugar-free peptone media is scant, with a thin, tough but rapidly disintegrating pellicle in broth. Gelatine is not liquefied. Milk is slowly clarified and becomes semi-transparent and viscous, with alkaline reaction Glucose, fructose, ethanol, glycerol and mannitol are readily utilized, mostly with acid formation $\mathrm{Xylose}$, galactose, di- and polysaccharides and numerous lower organic acids are not utilized Growth occurs at $p \mathrm{H}$ about 5-9 and only under aerobic conditions. Nitrogen fixation in liquid media is slow but may result in gains of nitrogen exceeding $20 \mathrm{mgm}$. per gm. glucose or mannitol supplied.

Molybdenum appears to be essential for nitrogen fixation and cannot be replaced by vanadium Fixed nitrogen (for example, ammonium and especially glutamic acid) allows a faster and more even growth than free nitrogen.

The organism differs markedly from Azotobacter inter alia by its typical long rod-shaped cells which except for the negative Gram-reaction and the lack of endospores resemble those of Bacillus. On the other hand it resembles the genus Beijerinckia in the tenacious growth on agar but differs by its muck larger cell size and the absence of typical polar fat globules. In our opinion this organism must be considered a separate group within the Azotobacter acer $^{1}$. A more detailed description will be published elsewhere.

Department of Bacteriology,

$$
\text { H. L. JENSEN }
$$

State Laboratory for Soil and Crop Research, Lyngby, Denmark.

$$
\text { P. K. DE }
$$

Roma Bhattacharya

State College of Agriculture, Calcutta-40, India. Sept.11.

1 Jensen, H. L., Bact. Rev., 18, 195 (1954).

\section{Nicotinamidase in Mycobacteria : A Method for Distinguishing Bovine Type Tubercle Bacilli from other Mycobacteria}

Bovine type tubercle bacilli have been differen tiated from other Mycobacteria by means of growth characteristics and pathogenecity for animals. They usually grow dysgonic in its original culture and are pathogenic for guinea pigs and rabbits. However, many laboratory strains of bovine tubercle bacilli now grow eugonic and can not be differentiated from growth characteristics, and furthermore, avirulent strains of bovine type tubercle bacilli like $B C G$ or isoniazid resistant bovine tubercle bacilli have been developed, and they can not be differentiated from animal pathogenecity. Konno et al. ${ }^{1,2}$ suggested simple chemical method to distinguish human tubercle bacilli from bovine tubercle bacilli or atypical Mycobacteria applying high nicotinic acid production of human tubercle bacilli. Halpern and Grossowicz" studied nicotinamidase activity of the extracts of $M$. phlei and $B C G$ and reported $M$. phlei revealed high nicotinamidase activity than $B C G$. Bönicke and Lisboa compared nicotinamidase of emulsion of human tubercle bacilli and bovine tubercle bacilli and 